\title{
Editorial to the special issue
}

\author{
The euro at 20 - macroeconomic challenges
}

\author{
Jan Behringer \\ Macroeconomic Policy Institute, Hans Böckler Foundation, Düsseldorf, Germany and fellow of the Forum for \\ Macroeconomics and Macroeconomic Policies (FMM)
}

Sebastian Gechert

Macroeconomic Policy Institute, Hans Böckler Foundation, Düsseldorf, Germany and fellow of the Forum for Macroeconomics and Macroeconomic Policies (FMM)

Jan Priewe

Macroeconomic Policy Institute, Hans Böckler Foundation, Düsseldorf and HTW Berlin - University of Applied Sciences, Germany and fellow of the Forum for Macroeconomics and Macroeconomic Policies (FMM)

Torsten Niechoj

Rhine-Waal University of Applied Sciences, Kamp-Lintfort, Germany and fellow of the Forum for Macroeconomics and Macroeconomic Policies (FMM)

\section{Andrew Watt}

Macroeconomic Policy Institute, Hans Böckler Foundation, Düsseldorf, Germany and fellow of the Forum for Macroeconomics and Macroeconomic Policies (FMM)

2019 marks the 20th anniversary of the introduction of the euro, replacing 11 national currencies. The two decades have been characterized by geographical extension to 19 countries, a modest increase in the euro's international role, but also by the build-up of unsustainable imbalances, and a long and deep economic and political crisis specific to many countries sharing the common currency. In response, substantial reforms have been undertaken without, however, resolving a number of key economic governance weaknesses. Since even before its birth, the euro has been a subject of controversial debate amongst economists of all schools. That debate has only intensified since the crisis. Now emerging into 'adulthood', serious questions remain. Is the common currency sustainable in something like its present form? What economic policies are feasible within the current framework? What crucial reforms need to be pushed through? Could a path back to national currencies be trodden while avoiding a major crisis?

This special issue addresses these questions and provides both a retrospective of the evolution of the euro area and an outlook from a political economy perspective. It draws on selected contributions to the panels of the 23rd conference of the Forum for Macroeconomics and Macroeconomic Policies on 'The euro at 20 - macroeconomic challenges', which took place in Berlin from 24 to 26 October 2019.

Agnès Bénassy-Quéré holds that the euro area crisis was less a crisis of the euro than a crisis of the Maastricht doctrine. The latter was based on a triple ban: no monetization of fiscal deficits, no bail-out, no sovereign default. The euro architecture was also based on a strict division of tasks: the European Central Bank would stabilize prices in the euro area as a whole, whereas national governments would stabilize their own economies in case of idiosyncratic shocks. To make things even more dysfunctional, bank supervision remained 
under the competence of the member states. Although much has been done since the crisis to reform the Maastricht framework, there are still major flaws which weaken the single currency. She sees such institutional flaws in the still unresolved doom-loop of sovereign debt risks enclosed in bank balance sheets, the rather inefficient fiscal policy framework of the Stability and Growth Pact, the deflation bias via higher fiscal saving in high-debt countries and downward wage competition inducing low inflation, among others. Higher public investment alongside the Green Deal and some kind of wage coordination are recommended. It will take much more than 20 years to overcome the initial flaws of the euro's design.

Jörg Bibow assesses the functioning of Europe's Economic and Monetary Union during the first 20 years of the euro's existence. He argues that two formative intellectual currents converged at Maastricht to shape the design and reception of the euro regime: ordoliberalism and neoliberalism. Germany's ordoliberalism inspired and shaped the design. Neoliberalism fashioned the reception of what was agreed at Maastricht under the influence of Bundesbank dogma and power. As a product of the zeitgeist, Europe got stuck with a deeply flawed euro architecture. The Maastricht Treaty institutionalized an asymmetric (growth-unfriendly) policy regime. This suited the macroeconomic mainstream well, fighting the '1970s stagflation war' for the past 40 years. Twenty years of euro disillusion have produced the exact opposite: 'stagdeflation'. Despite reforms in the euro area the basic neoliberal mantra is still alive. He argues 'that euro area officialdom and mainstream academia continue barking up the wrong tree until today'. At the roots of the flawed design, Bibow sees the disconnect between monetary and fiscal policy. The lack of a common Treasury against symmetric shocks is reinforced by the contractionary bias of the fiscal policy stance in the fiscal rulebook, while monetary policy's power is limited. The author's outlook for the future of the euro seems gloomy.

In the article 'Fiscal policies in a monetary union: the eurozone case', Gennaro Zezza argues that the Great Recession of 2008-2009 has changed the picture with respect to the fiscal framework. For some years, the old Maastricht setting was partly suspended and replaced by pragmatic interventionism. After the crisis, however, the picture has changed back towards the old institutional framework of fiscal consolidation resulting in unemployment and slow growth in several European countries. In such a situation, these countries had to realize external surpluses to avoid a worsening of private-sector performance. He concludes that this has created a fragile and crisis-prone situation.

In his contribution, Peter Bofinger, former member of the German Council of Economic Advisors, assesses the impact of the presidency of Mario Draghi, third president of the European Central Bank, in contrast to its predecessor Jean-Claude Trichet. Bofinger notes that Draghi was highly criticized because of his 'whatever it takes' approach by German media and German economists. According to Bofinger, however, this was necessary to avoid the collapse of the euro area. Moreover, the often invoked negative externalities of Draghi's monetary policies have, so far at least, not manifested themselves.

Vítor Constâncio, former vice-president of the European Central Bank and now at the University of Lisbon, takes as his starting point that the euro is irreversible but it nevertheless needs reform to address both existing design deficiencies and also new challenges. Although progress has been made, further steps are needed, the most important of which are: revision of the fiscal rules to avoid pro-cyclicality; establishing a central stabilization capacity; completing a banking union (especially a deposit insurance); establishing a capital market union based around a common safe asset; and implementing improved macroprudential policy. He sets out detailed reform proposals for the fiscal framework, focusing on an expenditure rule to be linked with a stabilization capacity. If a genuinely safe European asset is created, the euro can start to fulfil its potential, both domestically and internationally. 